\title{
The Role of Innovation Efforts in Raising the Growth Performance of Technology and Knowledge-Based Small and Medium-Sized Firms. Evidence from the Italian Context
}

\author{
Benigno D'Orazio \\ Via Milano n. 2, 64025 Pineto - Teramo \\ Italy
}

\begin{abstract}
The paper aims to investigate, from a theoretical and empirical point of view, the effect emerging from the firm's innovative activity on the growth performance of technology and knowledge-based small and medium-sized enterprises (SMEs), with particular reference to university spin-offs (USOS). The results from the analysis conducted on a panel sample of 474 Italian USOs falling into the size category of SMEs, investigated in the time period between 2006 and 2014, highlight how the ability to generate innovation has positive effects on their growth performance, in terms of sales revenues. This evidence emphasizes how the effects generated by innovative efforts increase the level of business growth. Therefore, the results of the study support the theoretical proposal according to which the innovative activity of companies is one of the main contributors to the performance outcomes of technology and knowledge-based SMEs.
\end{abstract}

Keywords: technology and knowledge-based small and medium-sized enterprises; SMEs; university spin-offs, USOs, firm innovation; firm growth.

\section{Introduction}

Innovation is recognized as a dominant factor in the consolidation of global competitiveness (Feldman et al., 2019). In fact, it stimulates organizational growth and constitutes the driving force that allows the corporate system to support its economic activities in the complex socio-economic system (Grover Goswami et al., 2019; Bravo-Biosca et al., 2016). Classical scholars in the economic-business field support this concept, legitimizing it as a constitutive element of entrepreneurship (Rinne et al., 2012; Schumpeter, 1982). Further, some scholars postulate how small and medium-sized enterprises (SMEs) can make significant profits from adapting to environmental changes in a more dynamic way than larger companies; thanks also to their lean structure without formalized hierarchies, as well as to the speed of the decision-making process (Miroshnychenko et al., 2020; Follesa, 2014). Furthermore, the socio-economic context attributes greater potential value and greater positive externalities to SMEs that invest significantly in innovation than large organizations (Lee and Chen, 2009; Loon and Chik, 2019).

In contrast, some of the literature has observed that innovation requires huge resources (Troilo et al., 2014). This element poses significant challenges regarding the effective possibility of innovating SMEs, which usually invest limited resources for innovative-based projects. (Acs and Audretsch, 1988). Furthermore, innovation implies a greater degree of uncertainty and potential risks (Teece and Leih, 2016). While larger organizations are more successful in absorbing failures deriving from innovative processes, for SMEs the failure of an innovative output evokes existential risks (Bloch and Bhattacharya, 2016). Furthermore, large firms are usually familiar and experienced with innovative projects, which also lead to organizational innovations (Majchrzak et al., 2004; Danneels, 2002). SMEs, especially newly established ones, often do not possess such organizational skills and requirements and, in this way, the risk deriving from inexperience produces negative effects on organizationalmanagerial results. Therefore, it follows that innovation is a process characterized by high risk elements which increase the probability of failure (Berggren and Nacher, 2001), or which at least do not generate a sufficiently adequate return on performance in the short term (Block and MacMillan, 1993). Furthermore, several empirical studies investigating the relationship between innovation and business performance have often found heterogeneous results. Some evidence shows that innovation does not generate any (or at least only partial) influencing effect on firm performance (Löfsten, 2014); other studies, on the other hand, do not detect negative effects of innovative business activity (Vermeulen et al, 2005). More properly, as regards the relationship between innovation and business growth, literature considers it as a particular configuration of a paradoxical relationship. On the one hand, a wide range of theoretical contributions and descriptive analyzes about business growth attributes the important and effective role of innovation in expanding the market share of the business, as well as their business opportunities (Carden, 2005; Geroski, 2005); these elements are confirmed above all in the studies on SMEs (Hay and Kamshad, 1994). On the other hand, empirical studies have revealed problems in identifying any strong link between innovation and business growth, frustrating the exploration of potential causal effects. Therefore, literature calls for a systematic analysis of the innovation-performance relationship in SMEs in order to better understand the elements and dynamics that support the growth of this particular type of entrepreneurial class. This is true for those SMEs operating in high technological and knowledge sectors, in which the innovative process assumes greater importance as the very essence of the future development of the business (Colombelli et al., 2014; 
Löfsten and Löfsten, 2016). In fact, these companies are counted as an important source of new employment, as well as key promoters of technological change, innovation and economic growth (Gianfelici, 2009). In the context of technological and knowledge-based companies, the launch of an innovative process is not simply configured as a potential tool for organizational development but, above all, as a critical element for building and strengthening their competitive advantage, as well as the survival of the firm (Löfsten and Löfsten, 2016), which firmly depends on its ability to generate new knowledge and new technological domains (Cefis and Marsili, 2005; Santarelli and Vivarelli, 2007). Therefore, the analysis of the innovation-performance relationship in technological and knowledge-based SMEs acquired greater relevance because of the natural link that exists between the development of an effective and widespread innovative process and the resilient development of the organization.

The study seeks to help fill the knowledge gap found in the above arguments, by investigating the effect of innovation on the growth of the company in a particular type of technology and knowledge-based SMEs, namely the university spin-offs (USOs). In fact, the interest of scholars about the dynamics of growth and the mechanisms promoting the innovation of USOs has increased significantly in recent years (Galati et al., 2017; Rodeiro-Pazos et al., 2012). USOs are companies, usually small and medium-sized, created with the aim of commercializing the knowledge or technology developed in the academic environment (Algieri et al., 2013; Rasmussen et al., 2014). Consequently, their fundamental contribution to the knowledge economy is their ability to generate innovation (Rodríguez-Gulías et al., 2016), as well as direct and indirect externalities on economic growth (Iacobucci and Micozzi, 2015). Consequently, USOs constitute an optimal exploratory basis for the purposes of the systematic analysis of the causal elements that link innovation to business growth in technology and knowledge-based SMEs. From an empirical point of view, a panel sample of 474 USOs belonging to the SME size range, extracted from the Netval database and investigated in the 2006-2014 period, was analyzed.

\section{Theoretical background}

In view of the relevant role assumed by SMEs for economic and technological development, their innovative processes and outputs have received considerable interest from the literature (Agostini et al., 2017; Bloch and Bhattacharya, 2016; Acs and Audretsch, 1988). In particular, a considerable part of the studies emphasizes and underline the role of innovative capacity as an element that promotes and guides the performance and growth of SMEs (Li and Mitchell, 2009; Rosenbusch et al, 2011). Although SMEs generally face significant resource constraints (Terziovski, 2010), they are often successful innovators (Rosenbusch et al, 2011), thanks to their small and agile organizational structure, as well as a very flexible entrepreneurial approach, promoted by managers and founders, able to stimulate the innovative process. Schumpeter (1934) argues that innovation is an opportunity for entrepreneurial firms to obtain income through the temporary establishment of a monopoly, and considers the activity of continuous innovation as the main long-term source of success entrepreneurial. Since SMEs are more agile than their larger counterparts, they can react more quickly and contingently to environmental changes and, consequently, obtain these monopoly rents for a longer period of time.

Furthermore, the innovative development process is considered an idiosyncratic dynamic capacity dependent on the entrepreneurial path undertaken by SMEs (Triguero et al., 2014; McAdam et al., 2014). It leads to a competitive advantage through the enhancement, recombination or creation of resources and their distribution in value creation strategies (Huhtala et al., 2016; Serio and Visconti, 2015). The ability to reconfigure their resource base for greater organizational agility and adaptability is a significant advantage of SMEs over larger companies. In consideration of this and from the point of view of dynamic capabilities, SMEs can profitably benefit from innovative activity. In addition to the direct effects on performance, learning from the innovation process (Mahmoud et al., 2016) generates absorption capacity, also defined as the ability to identify, assimilate and apply knowledge. This is especially true in technology and knowledge-based SMEs (Díez-Vial and Fernández-Olmos, 2015).

The absorption capacity emerging from innovative activities and outputs, consequently, generates competitive advantages over competitors, allowing them to achieve superior performance (Li and Mitchell, 2009; Rosenbusch et al., 2011). Additional benefits of innovation include economies of learning, economies of scale and scope, the preemption of limited resources, as well as incremental benefits of new innovation, which leverages growth and continuous improvement (Gawer, 2014).

Further, it should be noted that the theoretical framework of the Resource Based-View (RBV) has been widely employed as a conceptual basis for a systematic understanding of how the firm's resources drive its performance (Crook et al., 2008). Many scholars, however, have argued that it is the firm's ability to allocate resources that most accurately explains corporate performance differentials (Newbert, 2007). More properly, an entrepreneurial ability is defined as the set of interconnected processes in order to perform specific tasks (O'Cass and Sok, 2012). As such, it is a critical element for companies to develop capabilities and achieve superior performance in specific markets and technology domains (Sok et al., 2013). In this context, O'Dwyer et al. (2009) and Vorhies et al. (2009) have validated the ability to innovate as a significant contributory element of the company's success and resilient growth. 
With specific regard to the USOs, scholars advocate that the RBV is an effective theoretical framework for the development of exploratory investigations on the effectiveness of spin-out processes and related technology transfer activities from universities (Vinig and Van Rijsbergen, 2010). In particular, it was observed that RBV is closely linked to financial resources, human capital, organizational factors of universities and the spin-off company itself (Powers and McDougall, 2005), as well as its ability to generate and disseminate innovation (RodríguezGulías et al., 2016). These elements are mutually and complementarily linked to the fundamental drivers of the performance and growth of the USO (Rasmussen et al., 2014).

Therefore, on the basis of the elements and theoretical arguments discussed, it is possible to assert that the innovative processes and outputs activated by technology and knowledge-based SMEs, in the form of USO, constitute a citric and valid driver for the subsequent development of a long-term growth process of the company. In consideration of this, the following research hypothesis is put forward:

Hypothesis: The innovation of technology and knowledge-based SMEs, in the form of USO, is positively associated with the growth of the firm.

\section{Method}

\subsection{Sample and data}

To verify the definite research hypothesis, a panel sample of 474 Italian USOs was analyzed in a size class of SMEs (following one of the categorical criteria of the European Commission: firms having less than 250 persons employed) were extracted from the Netval database (part of the "Spin-off Italy" project and were partnered with Netval, Marche Polytechnic University and Sant'Anna Superior School). The sample covers a period from 2006 to 2014. Lastly, the secondary data of spin-off was used to track the balance sheet and other social documents extracted from the Aida BvD database, an Italian subset of the ORBIS database, collecting financial, biographical and merceological information about 700,000 Italian firms. Lastly, information about patent activity from spin-offs was collected from ESPACENET database.

\subsection{Dependent variable}

The dynamics about firm growth are considered an important measure of firm performance. In this regard, the most common indicators are related with growth in terms of the number of employees in the company and in terms of sales revenues (Wennberg et al., 2011). Since employment growth depends on changes in staff productivity resulting from technological advances, together with the extent of funding received by spin-offs (Hayter 2011), sales growth was selected as a proxy for growth performance by USOs (GROWTH). In detail, the variable was calculated in logarithmic terms using the following ratio: net revenues $\mathrm{s}_{\mathrm{t}} /$ net revenues $_{\mathrm{t}-1}$.

\subsection{Independent variable}

The patent activity was used in order to measure the innovative performance of USOs. In fact, patents are generally accepted indicators for analyzing the company's innovative capacity (Dahlstrand, 1997), as well as the intensity of the entrepreneurial effort in the innovation process (Lee and Lee, 2013). More specifically, the literature on USOs has mainly employed patent activity as a proxy for innovative performance (Rodriguez-Gulías et al., 2016). Therefore, it follows that the independent variable (INNOVATION) was created using a dummy for each year analyzed assuming value 1 if the spin-off has patent activity in the year, and 0 in other cases. The patent activity used in this study involves both patent applications and patents granted at any level (filed with the Italian Patent and Trademark Office (UIBM), the US Patent and Trademark Office (USPTO) or at other national patent offices, and submitted to the European Patent Office (EPO) or to a Patent Cooperation Treaty (PCT)).

\subsection{Control variables}

In order to control potential additional effects on firm growth, a set of control variables was used. Firstly, variables related to the performance and financial structure dynamics of the firm were used: in detail, the current liquidity index (CURRENT LIQUIDITY) was used, given by the ratio between current assets and debts,

The turnover index of assets (ASSET TURNOVER) given by the ratio between sales revenues and total company activities, together with the leverage index (LEVERAGE) given by the ratio between the company debt and total loans. In order to control the effects deriving from the firm size, the natural logarithm of the total assets (DIMENSION) was used, while the effects related to the firm age were examined using a variable measuring the years of existence of the company starting from their constitution (AGE). 


\section{Analytical Investigation Approach}

The analysis of the potential positive effects exerted by the innovative activity carried out by technology and knowledge-based SMEs, with particular reference to USOs, on their growth performance, was conducted according to an empirical approach articulate in two moments of investigation. In particular, in the first, descriptive statistics and Pearson's bivariate correlation analysis were performed; in the second, instead, aimed at empirically validating the research hypothesis developed, a multiple regression model estimated was defined. In detail, the following linear regression model has been developed, which includes both temporal effects and fixed effects:

GROWTH_it $=\beta \_1$ INNOVATION_it $+\beta \_3$ CONTROLS_it $+\varepsilon \_$it

Where CONTROLS represents the vector of control variables that potentially and presumably affect business growth and not innovation, while $\varepsilon_{-}$it represents the error term for company $i$ at time $t$

\section{Results}

\subsection{Descriptive statistics}

Table 1 reports the descriptive statistics computed on the variables used in the analysis models. The 474 USOs investigated have, on average, a growth indicator value in terms of sales revenues of 0.17 . This evidence identifies a low capacity for growth and development of technology and knowledge-based SMEs analyzed, confirming the trend already highlighted in the most accredited literature on the subject regarding the difficulties of achieving successful entrepreneurial performance by USOs, especially in the European context (Galati et al., 2017). However, the data relating to the S.D. (0.86) denotes a medium-high dispersion between the growth performances achieved by the companies surveyed. Further, the innovative performances achieved by the USOs analyzed show an average of 0.05 of the dichotomous variables used, highlighting that only about the $5 \%$ of the sample carried out patent activities. Consistent with growth performance, this evidence places limits on the ability of technology and knowledge-based SMEs to develop and disseminate innovations. This assertion is further strengthened by the low sample dispersion detected by the standard deviation (0.23).

Table 1. Descriptive statistics

\begin{tabular}{llllll}
\hline \multicolumn{1}{c}{ Variable } & N & Mean & S.D. & Min & Max \\
\hline GROWTH & 1,625 & .1790661 & .8633159 & -7.475739 & 8.499762 \\
INNOVATION & 1,625 & .0596923 & .2369888 & 0 & 1 \\
CURRENT LIQUIDITY & 1,625 & 1.927108 & 1.454712 & .02 & 9.6 \\
ASSET TURNOVER & 1,625 & .9192677 & .6012279 & 0 & 3.57 \\
FIRM SIZE & 1,625 & 5.955136 & 1.3278 & 2.23559 & 11.91221 \\
LEVERAGE & 1,625 & .5720205 & .2627883 & .0310727 & 3.724872 \\
FIRM AGE & 1,625 & 7.603288 & .0024245 & 7.591357 & 7.607381
\end{tabular}

Table 2 shows the Pearson correlation statistics computed for the variables under analysis. The absence of high sufficiently significant correlations between the explanatory variables indicates that multicollinearity does not constitute a serious critical element and it is therefore possible to proceed with regression analysis according to the defined model.

Table 2. Pearson correlation statistics

\begin{tabular}{lllllllll}
\hline & & \multicolumn{1}{c}{1} & \multicolumn{1}{c}{2} & 3 & 4 & 5 & 6 & 7 \\
1 & GROWTH & 1 & & & & & & \\
2 & INNOVATION & 0.0396 & 1 & & & & & \\
3 & CURRENT & -0.0378 & 0.0420 & 1 & & & & \\
& LIQUIDITY & & & & & & & \\
4 & ASSET & $0.1390^{*}$ & $-0.1235^{*}$ & $-0.0909^{*}$ & 1 & & & \\
& TURNOVER & & & & & & & \\
5 & FIRM SIZE & -0.0027 & $0.1381^{*}$ & $-0.0525^{*}$ & $-0.2625^{*}$ & 1 & & \\
6 & LEVERAGE & -0.0358 & $-0.0957^{*}$ & $-0.5881^{*}$ & 0.0289 & $0.0858^{*}$ & 1 & \\
7 & FIRM AGE & $0.1412^{*}$ & -0.0140 & 0.0476 & -0.0004 & $-0.4793^{*}$ & $-0.0776^{*}$ & 1
\end{tabular}

Note: * The correlation is significant at the 0.05 (2-tailed) level.

\subsection{Regression model estimation}


Table 3 shows the results emerging from the estimation of the linear regression model developed in the research work, which is aimed at analyzing the effect generated by the innovation achieved by USOs on their growth in terms of revenues from sales. In particular, the regression analyzes are carried out following the step-wise method: in column (i) the estimates of the control variables only, while in column (ii) the estimates of the main effect investigated are also included, i.e. the innovation achieved by the USOs. The results from the regression model show that the parameter estimated on the INNOVATION variable is positive and statistically significant (column (ii); coefficient $=0.1488161, \mathrm{p}<0.05)$. This evidence highlights how the innovative efforts achieved by USOs contribute significantly to the achievement of superior business growth performance. Therefore, based on the emerging empirical results, it is possible to support the research hypothesis developed.

Table 3.Linear regression model estimation.

\begin{tabular}{|c|c|c|}
\hline Dependent variable: GROWTH & (i) & (ii) \\
\hline INNOVATION & & $\begin{array}{l}.1488161 * \\
(.0896251)\end{array}$ \\
\hline \multicolumn{3}{|l|}{ Control variables: } \\
\hline CURRENT LIQUIDITY & $\begin{array}{l}-.0418615 * * * \\
(.0177772)\end{array}$ & $\begin{array}{l}-.0411089 * * \\
(.0177733)\end{array}$ \\
\hline ASSET TURNOVER & $\begin{array}{l}.2485783 * * * \\
(.0365014)\end{array}$ & $\begin{array}{l}.2534966 \text { *** } \\
(.0366016)\end{array}$ \\
\hline FIRM SIZE & $\begin{array}{l}.0946729 * * * \\
(.018774)\end{array}$ & $\begin{array}{l}.0907325 * * * \\
(.0189133)\end{array}$ \\
\hline LEVERAGE & $\begin{array}{l}-.2583276 \text { *** } \\
(.0982458)\end{array}$ & $\begin{array}{l}-.2421647 * * \\
(.0986738)\end{array}$ \\
\hline FIRM AGE & $\begin{array}{l}74.16774 * * * \\
(9.90053)\end{array}$ & $\begin{array}{l}73.45233^{* * * *} \\
(9.904538)\end{array}$ \\
\hline Number of obs & 1,625 & 1,625 \\
\hline $\mathrm{F}$ & $20.14 * * *$ & $17.26^{* * *}$ \\
\hline R-squared & 0.0585 & 0.0602 \\
\hline Adj R-squared & 0.0556 & 0.0567 \\
\hline Root MSE & .83895 & .8385 \\
\hline
\end{tabular}

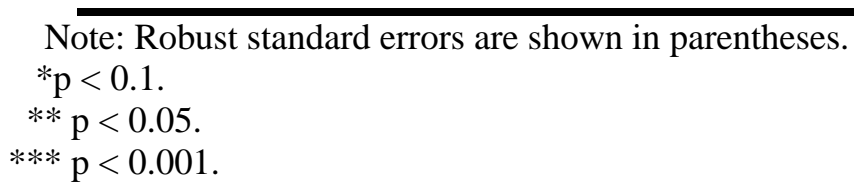

\section{Result discussion and conclusion}

The research work aimed to investigate, from a theoretical and empirical point of view, the effect deriving from the company's innovative activity on the growth performance of technology and knowledge-based SMEs, with particular reference to USOs, which constitute a qualifying and highly significant sub-set of the typological class of enterprise analyzed.

The results from the analysis conducted on a panel sample of 474 Italian USOs falling into the size category of SMEs, investigated in the time period between 2006 and 2014, highlight how the ability to generate innovation of this typological class has positive effects and promoting their growth performance, in terms of sales revenues. This evidence is consistent with the results emerging from previous empirical studies, emphasizing how the effects generated by innovative efforts increase the level of business growth, thanks to the improved positioning of the target market, the pursuit of new business opportunities,

The achievement of a knowledge economy and the economic exploitation of new technological domains. Therefore, the results of the study support the theoretical proposal according to which the innovative activity of companies is one of the main contributors to the performance results of technology and knowledge-based SMEs. Likewise, the results highlight the importance of innovative capacity and performance as effective and relevant precursors of income performance in SMEs, as the dynamics linked to growth investigated here have been analyzed in terms of sales revenues, which act to an extent decisive on the economic and financial results. The study seeks to offer several contributions to the literature. Firstly, the research partially supports the extension of previous studies on the analysis of the causal relationship between innovation and business growth in SMEs, with particular reference to those operating in sectors with a high technological and cognitive content. Furthermore, the study 
intends to constitute a partial theoretical and empirical contribution which is fundamental in the context of studies on USOs, increasing the basis for the determination of a framework aimed at the systematic analysis of the agents determining the growth of this peculiar form of enterprise.

Furthermore, the study aims to provide some significant insights and implications from a practical-managerial point of view. In detail, the evidence arising from the analysis is functional to the definition of optimized strategic actions and choices aimed at a better positioning of technology and knowledge-based SMEs in the market, allowing for full and effective development. In this regard, entrepreneurs of and managers need to develop long-term strategic plans that guarantee a constant offer of new products, new organizational and marketing methods and approaches in order to position the company in a more competitive way in the market and increases its competitive advantage. This is undoubtedly a decisive element, albeit not exclusive and sufficient, for the full development of the company and its resilient growth. To this end, it is above all necessary for the company to invest significantly in Research \& Development, especially in the development of new technologies, in knowledge management and in organizational learning, as well as encouraging the establishment and consolidation of wide-ranging inter-organizational relationships, mainly oriented towards open innovation (Brunswicker and Vanhaverbeke, 2015; Henttonen and Lehtimäki, 2017).

\section{References}

Acs, Z. J., \&Audretsch, D. B. (1988). Innovation in large and small firms: an empirical analysis. The American economicreview, 678-690.

Agostini, L., Agostini, L., Nosella, A., Nosella, A., Filippini, R., \& Filippini, R. (2017). Does intellectual capital allow improving innovation performance? A quantitative analysis in the SME context. Journal of Intellectual Capital, 18(2), 400-418.

Algieri, B., Aquino, A., \&Succurro, M. (2013). Technology transfer offices and academic spin-off creation: the case of Italy. The Journal of Technology Transfer, 38(4), 382-400.

Altinay, L., Madanoglu, M., De Vita, G., Arasli, H., \&Ekinci, Y. (2015). The interface between organizational learning capability, entrepreneurial orientation, and SME growth. Journal of Small Business Management.

Bagnoli, C., \&Vedovato, M. (2014). The impact of knowledge management and strategy configuration coherence on SME performance. Journal of Management \& Governance, 18(2), 615-647.

Berggren, E., \&Nacher, T. (2001). Introducing new products can be hazardous to your company: Use the right newsolutions delivery tools. The Academy of Management Executive, 15(3), 92-101.

Bloch, H., \& Bhattacharya, M. (2016). Promotion of Innovation and Job Growth in Small- and Medium- Sized Enterprises in Australia: Evidence and Policy Issues. Australian Economic Review, 49(2), 192-199.

Block. Z..\& MacMillan, I, C. (1993). Corporate venturing: Creating new busines.ses within the firm. Boston: Harvard Business School Press.

Bravo-Biosca, A., Criscuolo, C., \& Menon, C. (2016). What drives the dynamics of business growth?. Economic Policy, 31(88), 703-742.

Brunswicker, S., \&Vanhaverbeke, W. (2015). Open innovation in small and medium- sized enterprises (SMEs): External knowledge sourcing strategies and internal organizational facilitators. Journal of Small Business Management, 53(4), 1241-1263.

Carden, S.D. (2005). What global executives think about growth and risk. McKinsey Quarterly (2), 16-25.

Cefis, E., \&Marsili, O. (2005). A matter of life and death: innovation and firm survival. Industrial and Corporate change, 14(6), 1167-1192.

Coad, A., \& Rao, R. (2008). Innovation and firm growth in high-tech sectors: A quantile regression approach. Research policy, 37(4), 633-648.

Colombelli, A., Krafft, J., \&Quatraro, F. (2014). High-growth firms and technological knowledge: do gazelles follow exploration or exploitation strategies?. Industrial and Corporate Change, 23(1), 261-291.

Consorti, A. (1994). Il successo dell'azienda: schema di analisi.Giappichelli.

Crook, T. R., Ketchen, D. J., Combs, J. G., \& Todd, S. Y. (2008). Strategic resources and performance: a meta- analysis. Strategic management journal, 29(11), 1141-1154.

D’Amico, L., Consorti, A., Migliori S., \& Monaco, E. (2010). Governance, Entrepreneurial Orientation and Performance in Italian SMEs, RENTXXIV- Research in Entrepreneurship and Small Business, pp. 1-15.

Dahlstrand, Å. L. (1997). Growth and inventiveness in technology-based spin-off firms. Research policy, 26(3), 331-344.

Danneels, E. (2002). The dynamics of product innovation and firm competences. Strategic management journal, 23(12), 1095-1121.

Deschryvere, M. (2014). R\&D, firm growth and the role of innovation persistence: an analysis of Finnish SMEs and large firms. Small Business Economics, 43(4), 767-785.

Díez-Vial, I., \& Fernández-Olmos, M. (2015). Knowledge spillovers in science and technology parks: how can firms benefit most?. The Journal of Technology Transfer, 40(1), 70-84. 
Feldman, P. R., Jacomossi, R. R., Barrichello, A., \&Morano, R. S. (2019). The relationship between Innovation and Global Competitiveness: The mediating role of Management Practices evaluated by Structural Equation Modeling. Review of Business Management, 21(2), 195-212.

Follesa, S. (2014). Pmi e «innovazionememore». Valorizzare le diversità culturali: i cataloghi tematici. Quaderni di ricerca sull'artigianato, 2(3), 473-488.

Galati, F., Bigliardi, B., Petroni, A., \&Marolla, G. (2017). Which factors are perceived as obstacles for the growth of Italian academic spin-offs?. Technology Analysis \& Strategic Management, 29(1), 84-104.

Gawer, A. (2014). Bridging differing perspectives on technological platforms: Toward an integrative framework. Research Policy, 43(7), 1239-1249.

Geroski, P. A. (2005). Understanding the implications of empirical work on corporate growth rates. Managerial and DecisionEconomics, 26(2), 129-138.

Gianfelici, C. (2009). I processi di crescita delle piccole e medie imprese. Quaderni di ricerca sull'artigianato, (53), 199-229.

Graves Jr, S. L., \&Frohwerk, A. (2009). Multilevel modeling and school psychology: A review and practical example. School Psychology Quarterly, 24(2), 84.

Grover Goswami, A., Medvedev, D., \&Olafsen, E. (2019). High-growth firms: Facts, fiction, and policy options for emerging economies. The World Bank.

Hair, J. F., Black, W. C., Babin, B. J., Anderson, R. E., \& Tatham, R. L. (1998). Multivariate data analysis .Uppersaddle River. Multivariate Data Analysis (5th ed) Upper Saddle River.

Hay, M., \&Kamshad, K. (1994). Small firm growth: intentions, implementation and impediments. Business Strategy Review, 5(3), 49-68.

Hayter, C. S. (2011). In search of the profit-maximizing actor: Motivations and definitions of success from nascent academic entrepreneurs. The Journal of Technology Transfer, 36(3), 340-352.

Henttonen, K., \&Lehtimäki, H. (2017). Open innovation in SMEs: collaboration modes and strategies for commercialization in technology intensive companies in forestry industry. European Journal of Innovation Management, 20(2).

Hox, Joop J. (2002). Multilevel Analysis: Techniques and Applications. Mahwah, NJ: Lawrence Erlbaum.

Huhtala, J. P., Vaniala, I., \&Tikkanen, H. (2016). Market Orientation and Innovation in Dynamic Competitive Markets. In Marketing Challenges in a Turbulent Business Environment (pp. 73-73). Springer International Publishing.

Iacobucci, D., \&Micozzi, A. (2015). How to evaluate the impact of academic spin-offs on local development: an empirical analysis of the Italian case. The Journal of Technology Transfer, 40(3), 434-452.

Lee, R. P., \& Chen, Q. (2009). The immediate impact of new product introductions on stock price: the role of firm resources and size. Journal of Product Innovation Management, 26(1), 97-107.

Li, X., \& Mitchell, R. K. (2009). The Pace and Stability of Small Enterprise Innovation in Highly Dynamic Economies: A China- Based Template. Journal of Small Business Management, 47(3), 370-397.

Löfsten, H. (2014). Product innovation processes and the trade-off between product innovation performance and business performance. European Journal of Innovation Management, 17(1), 61-84.

Löfsten, H., \&Löfsten, H. (2016). Organisational capabilities and the long-term survival of new technology-based firms. European Business Review, 28(3), 312-332.

Loon, M., \&Chik, R. (2019). Efficiency-centered, innovation-enabling business models of high tech SMEs: Evidence from Hong Kong. Asia Pacific Journal of Management, 36(1), 87-111.

Mahmoud, M. A., Blankson, C., Owusu-Frimpong, N., Nwankwo, S., \& Trang, T. P. (2016). Market orientation, learning orientation and business performance: The mediating role of innovation. International Journal of Bank Marketing, 34(5), 623-648.

Majchrzak, A., Cooper, L. P., \&Neece, O. E. (2004). Knowledge reuse for innovation. Management science, 50(2), 174-188.

McAdam, R., Reid, R., \& Shevlin, M. (2014). Determinants for innovation implementation at SME and inter SME levels within peripheral regions. International Journal of Entrepreneurial Behavior \& Research, 20(1), 6690.

Miroshnychenko, I., Strobl, A., Matzler, K., \& De Massis, A. (2020). Absorptive capacity, strategic flexibility, and business model innovation: Empirical evidence from Italian SMEs. Journal of Business Research.

Newbert, S. L. (2007). Empirical research on the resource- based view of the firm: an assessment and suggestions for future research. Strategic management journal, 28(2), 121-146.

O'Cass, A., \&Sok, P. (2012). Examining the role of within functional area resource-capability complementarity in achieving customer and product-based performance outcomes. Journal of Strategic Marketing, 20(4), 345363.

O'Dwyer, M., Gilmore, A., \& Carson, D. (2009). Innovative marketing in SMEs. European Journal of Marketing, 43(1/2), 46-61. 
Paolone, G., \& D'Amico, L. (a cura di) (2011). L'Economia Aziendale nei suoi principi parametrici e modelli applicativi, Torino, Giappichelli Editore.

Pazos, D. R., López, S. F., González, L. O., \&Sandiás, A. R. (2012). A resource-based view of university spin-off activity: New evidence from the Spanish case. Revista Europea de Dirección y Economía de la Empresa, 21(3), 255-265.

Powers, J. B., \&McDougall, P. P. (2005). University start-up formation and technology licensing with firms that go public: a resource-based view of academic entrepreneurship. Journal of business venturing, 20(3), 291311.

Rasmussen, E., Mosey, S., \& Wright, M. (2014). The influence of university departments on the evolution of entrepreneurial competencies in spin-off ventures. Research Policy, 43(1), 92-106.

Rinne, T., Steel, G. D., \& Fairweather, J. (2012). Hofstede and Shane revisited: The role of power distance and individualism in national-level innovation success. Cross-cultural research, 46(2), 91-108.

Rodríguez-Gulías, M. J., Rodeiro-Pazos, D., \& Fernández-López, S. (2016). Impact of venture capital on the growth of university spin-offs. In Multiple Helix Ecosystems for Sustainable Competitiveness (pp. 169183). Springer International Publishing.

Rodríguez-Gulías, M. J., Rodeiro-Pazos, D., \& Fernández-López, S. (2016). The regional effect on the innovative performance of university spin-offs: a multilevel approach. Journal of the Knowledge Economy, 7(4), 869889.

Rosenbusch, N., Brinckmann, J., \& Bausch, A. (2011). Is innovation always beneficial? A meta-analysis of the relationship between innovation and performance in SMEs. Journal of business Venturing, 26(4), 441-457.

Salvatore, A. (2015). Il processo di internazionalizzazione delle PMI. Quaderni di ricerca sull'artigianato, 3(1), 143-162.

Santarelli, E., \& Vivarelli, M. (2007). Entrepreneurship and the process of firms' entry, survival and growth. Industrial and corporate change, 16(3), 455-488.

Schumpeter, J. (1982). Theory of economic development. Moscow: Progress Publisher.

Schumpeter, J. A. (1934). The Theory of Economic Development, translation of second German edition by Redvers Opie, Harvard University Press, Cambridge MA.

Serio, L., \& Visconti, F. (2015). La competitività delle PMI in un 'economia senza confini: sfide strategiche e modelli di sviluppo. Quaderni di ricerca sull'artigianato, 3(1), 3-24.

Shek, D. T., \& Ma, C. (2011). Longitudinal data analysesusing linear mixedmodels in SPSS: concepts, procedures and illustrations. The Scientific World Journal, 11, 42-76.

Sok, P., O’Cass, A., \& Sok, K. M. (2013). Achieving superior SME performance: Overarching role of marketing, innovation, and learning capabilities. Australasian Marketing Journal (AMJ), 21(3), 161-167.

Teece, D., \& Leih, S. (2016). Uncertainty, Innovation, and Dynamic Capabilities. California Management Review, 58(4), 5-12.

Terziovski, M. (2010). Innovation practice and its performance implications in small and medium enterprises (SMEs) in the manufacturing sector: a resource- based view. Strategic Management Journal, 31(8), 892902.

Triguero, A., Córcoles, D., \& Cuerva, M. C. (2014). Persistence of innovation and firm's growth: evidence from a panel of SME and large Spanish manufacturing firms. Small business economics, 43(4), 787-804.

Troilo, G., De Luca, L. M., \& Atuahene- Gima, K. (2014). More innovation with less? A strategic contingency view of slack resources, information search, and radical innovation. Journal of Product Innovation Management, 31(2), 259-277.

Verbeke, G., \&Molenberghs, G. (2009). Linear mixed models for longitudinal data. Springer Science \& Business Media.

Vermeulen, P. A., De Jong, J. P., \&O'shaughnessy, K. C. (2005). Identifying key determinants for new product introductions and firm performance in small service firms. The Service Industries Journal, 25(5), 625-640.

Vinig, T., van Rijsbergen, P., \&Malach-Pines, A. (2010). University technology transfer: comparative study of US, European and Australian universities. Handbook of Research on High Technology Entrepreneurs, Edward Elgar, Cheltenham, 179-209.

Vorhies, D. W., Morgan, R. E., \& Autry, C. W. (2009). Product- market strategy and the marketing capabilities of the firm: impact on market effectiveness and cash flow performance. Strategic Management Journal, 30(12), 1310-1334.

Wennberg, K., Wiklund, J., \& Wright, M. (2011). The effectiveness of university knowledge spillovers: Performance differences between university spinoffs and corporate spinoffs. Research Policy, 40(8), 11281143. 